\title{
Komunikasi Matematis Siswa Dalam Menyelesaikan Masalah Persamaan Garis Ketika Folding Back
}

\author{
Intan Syafitri ${ }^{1}$, Susiswo ${ }^{1}$, Hendro Permadi $^{1}$ \\ ${ }^{1}$ Pendidikan Matematika-Universitas Negeri Malang
}

\begin{tabular}{l}
\hline INFO ARTIKEL \\
\hline Riwayat Artikel: \\
Diterima: $13-05-2019$ \\
Disetujui: $16-09-2019$ \\
\hline
\end{tabular}

\section{Kata kunci:}

mathematical communication; folding back; problem solving; straight line equation; komunikasi matematis; folding back; penyelesaian masalah; persamaan garis lurus

\author{
Alamat Korespondensi: \\ Intan Syafitri \\ Pendidikan Matematika \\ Universitas Negeri Malang \\ Jalan Semarang 5 Malang \\ E-mail: intansf19@gmail.com
}

\section{ABSTRAK}

Abstract: This research aims to the mathematical communication of students who experience folding back when solving mathematical problems. The eight grade students of SMP Islam Syabilurrosyad Malang have participated here. Student with high communication going through folding back effectively and clearly following logic reasoning. Student with high communication could write folding back result rightly and consecutively. Student with medium communication going through folding back after intervention. Student with medium communication have communicated folding back result clearly and consecutively but still there were mistakes in the last solution.

\begin{abstract}
Abstrak: Penelitian ini bertujuan untuk mendeskripsikan komunikasi matematis siswa yang mengalami folding back ketika menyelesaikan masalah matematika. Penelitian ini dilaksanakan di kelas VIII SMP Islam Syabilurrosyad kota Malang. Siswa dengan kemampuan tinggi mengomunikasikan folding backnya dengan efektif dan jelas disertai alasan logis. Subjek berkemampuan tinggi juga menuliskan respons hasil folding back nya dengan benar dan terurut. Subjek berkemampuan sedang mengalami folding back setelah adanya intervensi. Subjek mengomunikasikan hasil folding back dengan jelas dan terurut, namun masih terdapat kesalahan pada solusi akhir jawabannya.
\end{abstract}

Salah satu keterampilan yang diperlukan untuk menghadapi tantangan perkembangan zaman abad ke-21 yaitu keterampilan komunikasi. Pernyataan ini diperkuat oleh pernyataan asosiasi guru di Amerika Serikat (P21) yang mengemukakan bahwa komunikasi merupakan salah satu dari empat keterampilan yang diperlukan oleh siswa untuk dapat hidup di abad 21 (Scott, 2017). Pentingnya komunikasi juga menjadi salah satu fokus dari tujuan pembelajaran matematika, yaitu siswa diharapkan mampu mengomunikasikan gagasan dan penalarannya serta mampu menyusun bukti dengan menggunakan bahasa matematis, seperti simbol, tabel, diagram atau media lainnya. National Council of Teaching of Mathematics juga menyatakan bahwa komunikasi memiliki peranan penting dalam proses pembelajaran matematika dan siswa perlu melatih keterampilan komunikasi untuk menghadapi masa depannya (NCTM, 2000). Oleh karena itu, dapat disimpulkan bahwa komunikasi merupakan salah satu keterampilan yang harus dimiliki siswa dan menjadi salah satu fokus perhatian guru sebagai pendidik untuk melatih keterampilan tersebut pada saat proses pembelajaran.

Komunikasi berperan sebagai alat untuk mengetahui dan menilai pemahaman siswa dan sebagai pusat dari proses pembelajaran matematika (NCTM, 2000). Pada saat proses pembelajaran berlangsung, maka terjadi aktivitas komunikasi berupa interaksi antara guru dan siswa maupun antar siswa. Interaksi ini bisa terjadi dalam bentuk komunikasi lisan saat berdiskusi atau tulisan yaitu ketika siswa memberikan solusi terhadap sebuah permasalahan. (Walle dkk, 2010) menyatakan bahwa ketika siswa menyelesaikan masalah maka mereka dapat mengekspresikan proses berpikir dan gagasannya secara tertulis dan diperjelas secara lisan dengan menggunakan bahasanya sendiri. Selanjutnya, Brookhart (2010) menyatakan bahwa aktivitas penyelesaian masalah merupakan cara yang efektif untuk mengetahui kemampuan komunikasi matematis siswa.

Aktivitas penyelesaian masalah melibatkan proses berpikir seseorang dalam menggunakan pengetahuan atau pemahaman yang ia miliki untuk membentuk suatu pemahaman baru yang berkaitan dengan permasalahan. Lester dan Kehle juga menyatakan bahwa aktivitas penyelesaian masalah merupakan kegiatan yang melibatkan siswa dalam berbagai tindakan kognitif yaitu menghubungkan pengetahuan sebelumnya untuk menghasilkan pengetahuan baru yang berguna dalam proses penyelesaian masalah (dalam Yoe, 2009). (Kilpatrick dkk, 2001) menyatakan bahwa dalam menyelesaikan masalah diperlukan pemahaman siswa terhadap pengetahuan yang ia miliki sebagai dasar untuk mengembangkan pengetahuan baru. Pemahaman tersebut menurut Glasersfeld merupakan pengelolaan struktur pengetahuan siswa yang saling berkelanjutan (Pirie \& Kieren, 1994). Teori pemahaman ini telah banyak dikaji oleh para ahli salah satunya Pirie \& Kieren yaitu teori pertumbuhan pemahaman matematis. 
Pirie-Kieren (1989) menyebutkan ada delapan lapisan pertumbuhan pemahaman yang tidak saling linear. Pada saat siswa menemukan kendala ketika menyelesaikan masalah, maka ia akan kembali ke lapisan pemahaman sebelumnya untuk memperkuat pemahamannya (Pirie \& Kieren, 1994). Proses ini dikenal dengan istilah folding back dan setiap individu memiliki urutan proses folding back yang berbeda-beda ketika menyelesaikan suatu masalah (Pirie \& Kieren, 1994; Pirie \& Martin, 2000) Meel, 2003). Ini menunjukkan bahwa setiap individu memiliki cara yang berbeda dalam mengonstruksi pemahamannya karena disesuaikan dengan cara berpikir individu dalam memaknai informasi yang dimilikinya.

Folding back yang dialami seseorang ketika menyelesaikan masalah dapat dilihat melalui komunikasi siswa dalam menyampaikan solusi jawabannya baik secara lisan ataupun tulisan. Hal ini sejalan dengan (NCTM, 2000) yang menyatakan bahwa untuk menilai pemahaman siswa dapat dilihat melalui cara siswa mengomunikasikan solusi permasalahan dengan menggunakan representasi model, diagram dan simbol-simbol matematika. Hal ini sesuai dengan pernyataan (Uptegrove, 2015) yang menyatakan bahwa komunikasi memiliki kaitan yang sangat erat dengan aktivitas penyelesaian masalah matematika. Brookhart (2010) juga menyatakan bahwa dengan memberikan sebuah masalah dan siswa diminta untuk menyelesaikannya merupakan salah satu cara yang efektif untuk melihat kemampuan komunikasi matematis dari siswa tersebut. Lebih lanjut, Wilson \& Stein (2007) menyatakan bahwa subjek mengalami folding back ketika ia diminta untuk menyajikan atau mengomunikasikan ide-idenya dengan berbagai representasi, seperti simbolik, aljabar, visual (gambar) ataupun narasi.

Berdasarkan uraian yang telah dipaparkan, peneliti tertarik untuk mendeskripsikan komunikasi matematis siswa yang mengalami folding back ketika menyelesaikan masalah. Permasalahan yang diberikan merupakan materi persamaan garis lurus dengan pertimbangan bahwa materi ini memerlukan pengetahuan seperti aljabar, koordinat cartesius, gradien, serta kedudukan titik dan garis. Komunikasi ini dideskripsikan berdasarkan kriteria Cognitive Assessment Instrument (QCAI), yaitu (1) adanya respons yang jelas, (2) mengomunikasikan ide dengan efektif, dan (3) menyajikan argumen yang logis dan mendukung.

\section{METODE}

Penelitian ini tergolong ke dalam penelitian kualitatif yang bertujuan untuk mendeskripsikan komunikasi matematis siswa dalam menyelesaikan masalah ketika folding back. Komunikasi matematis yang dideskripsikan yaitu proses komunikasi matematis siswa dalam menyelesaikan masalah ketika folding back. Subjek penelitian diambil dari siswa SMP kelas VIII yang dikategorikan ke dalam dua kelompok yaitu siswa berkemampuan matematika tinggi dan sedang. Pengelompokkan ini didasarkan pada nilai ulangan harian materi persamaan garis lurus dan diperkuat dengan saran dari guru matematika. Selanjutnya siswa diminta untuk menyelesaikan masalah dengan materi persamaan garis lurus. Berdasarkan solusi penyelesaian tersebut maka dipilihlah subjek dengan menggunakan teknik purposeful sampling yaitu subjek yang mengalami folding back dan dapat menyelesaikan keseluruhan permasalahan. Subjek yang dipilih yaitu satu subjek dari kemampuan matematika tinggi dan satu subjek dari kemampuan matematika sedang. Untuk mengonfirmasi jawaban dan mengetahui proses komunikasi matematis subjek secara detail maka langkah selanjutnya dilakukan wawancara. Setelah semua informasi dikumpulkan, peneliti kemudian mendeskripsikan seluruh data kedalam bentuk teks deskriptif. Terdapat dua instrumen yang digunakan, yaitu tes pemahaman dan pedoman wawancara. Berikut instrumen tes pemahaman yang digunakan pada penelitian ini.

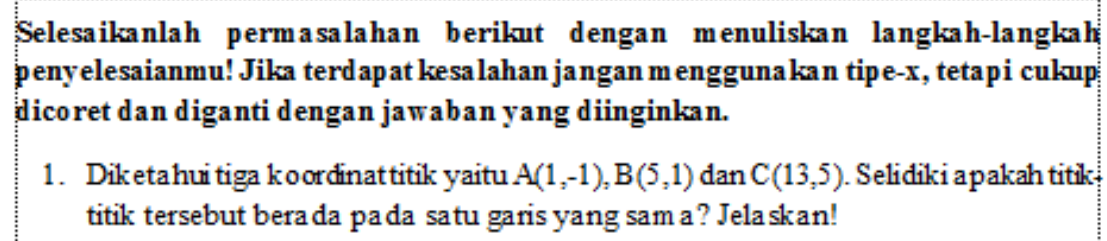

1. Diketa hui tiga koordinattitik yaitu $\mathrm{A}(1,-1), \mathrm{B}(5,1)$ dan $\mathrm{C}(13,5)$. Selidiki a pakah titik: titik tersebut berada pada satu garis yang sama? Jela skan!

\section{HASIL}

Berikut paparan hasil penelitian yang berfokus pada komunikasi matematis siswa yang mengalami folding back ketika menyelesaikan masalah matematika. Komunikasi yang dipaparkan berdasarkan pada kriteria komunikasi QCAI, yaitu (1) adanya respons yang jelas terhadap penyelesaian masalah, (2) mengomunikasikan ide matematis secara efektif, dan (3) menyajikan argumen yang logis yang mendukung penyelesaian masalah. Siswa yang terpilih menjadi subjek penelitian adalah A1 dari kelompok siswa berkemampuan tinggi dan B1 dari kelompok siswa berkemampuan sedang.

\section{Komunikasi Matematis Subjek A1 yang Mengalami Folding Back}

Subjek A1 secara keseluruhan menuliskan jawabannya cukup detail, jelas, dan komunikatif. Subjek A1 memulai solusinya dengan menginterpretasikan informasi yang diketahui ke dalam bentuk grafik garis lurus. A1 menentukan letak kordinat titik A, B dan C pada bidang kartesius dan kemudian menarik sebuah garis yang melewati ketiga titik tersebut. Gambar 1 menunjukkan solusi penyelesaian yang dikerjakan oleh A1. 


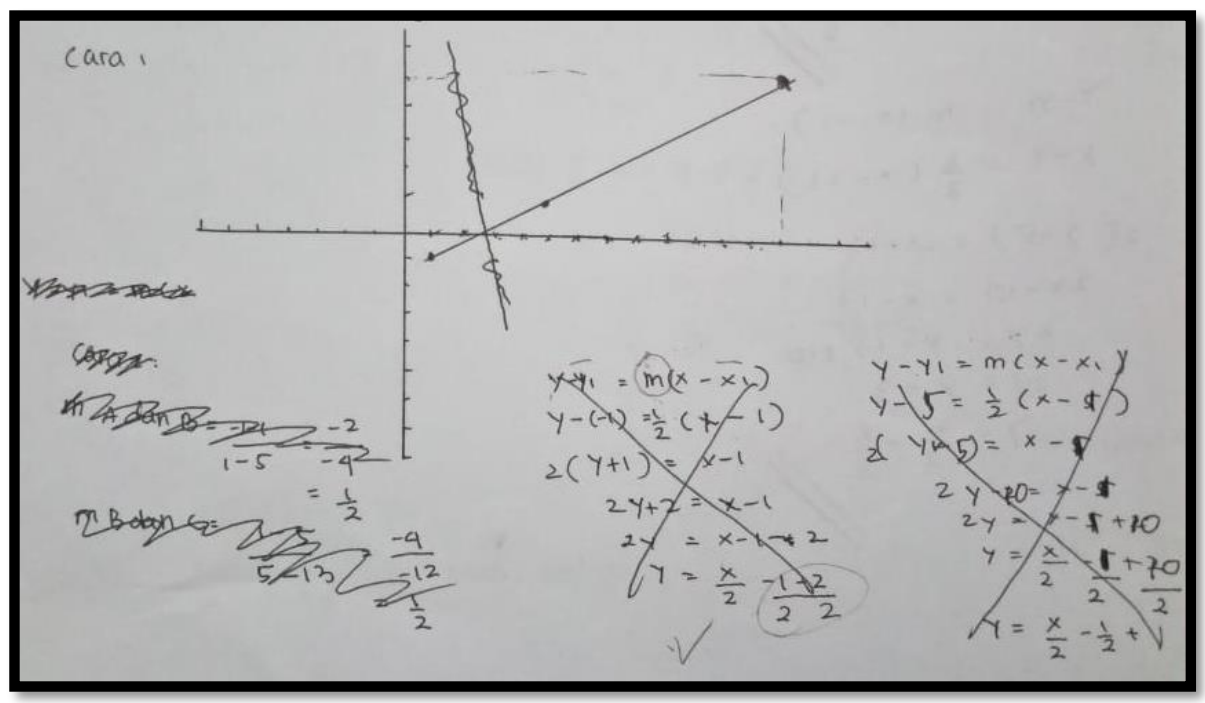

Gambar 1. Jawaban Subjek A1

Berdasarkan gambar 1, secara tertulis A1 sudah berada di lapisan pemahaman property noticing dengan menggambarkan grafik garis lurus berdasarkan informasi yang diketahui. Namun, subjek A1 tidak memberikan responsnya yang menunjukkan bahwa ia sudah memahami informasi dari permasalahan. Peneliti pun melakukan konfirmasi melalui wawancara dan mendapatkan respons secara lisan dari A1, sebagai berikut:

P : "Coba kamu jelaskan apa saja informasi yang kamu ketahui dari soal nomor 1?."

A1.1 : "Titik-titik yang diketahui ini apakah dilewati satu garis atau tidak mbak."

P : "lalu apa rencana yang akan kamu lakukan?"

A1.2 : "Saya gambarkan letak koordinat titiknya, terus dilihat apakah mereka satu garis mbak."

P : "Bagaimana cara kamu menggambarkannya."

A1.3 : "Pakai bidang koordinat kartesius mbak, yang ini garisnya mbak." (sambil menunjukkan Gambar 1)

P : "Lalu ini garis apa yang kamu coret?"

A1.4 : "Hehe, ini tadi saya salah menentukkan titiknya mbak, baru saya ingat lagi kalau ini untuk titik $x$ dan yang ini untuk titik y, terus saya garis mbak."

Wawancara di atas menunjukkan bahwa subjek mengalami folding back ke lapisan primitive knowing dengan menyebutkan pengetahuan sederhana yang ia miliki terkait permasalahan. Subjek A1 dapat memberikan resposnnya dengan jelas, benar dan menggunakan bahasa sendiri. Penjelasan subjek A1 ini juga menunjukkan bahwa ia telah bergerak kembali ke lapisan image making hingga image having. Subjek A1 menyebutkan strateginya untuk menyelesaikan masalah yaitu dengan menggambarkan letak koordinat titik yang diketahui dan menarik sebuah garis lurus yang melewati titik tersebut. Subjek mengomunikasikan responsnya ini dengan efektif dan dapat juga dipahami oleh peneliti. Selanjutnya, subjek menyebutkan pernyataan A1.4 yang menunjukkan bahwa subjek A1 mengalami kembali folding back dari lapisan property noticing ke lapisan primitive knowing. Folding back ini dilakukan untuk mengingat kembali cara menentukan letak koordinat titik pada bidang kartesius seperti pada pernyataan A1.4. Pernyatan tersebut juga menunjukkan bahwa subjek A1 dapat menyebutkan respons dan alasanya dengan jelas dan efektif ketika ia mengalami folding back.

Berdasarkan Gambar 1, subjek A1 melanjutkan penyelesaiannya dengan menuliskan perhitungan gradien untuk titik A dan B dan gradien untuk titik B dan C. Pada awalnya subjek A1 berpikir bahwa masalah ini dapat diselesaikan dengan menggunakan konsep gradien garis. Namun, subjek A1 melakukan folding back kembai ke lapisan image making untuk menemukan strategi yang tepat guna untuk menyelidiki apakah ketiga titik tersebut berada pada satu garis yang sama. Berikut lanjutan wawancara subjek A1.

P : : "Lalu bagian yang dicoret ini kamu tulisan apa?"

A1.5 : "Saya tadi awalnya mencari gradiennya mbak." (menunjuk pada tulisan yang dicoret)

$\mathrm{P} \quad:$ :Lalu? Kenapa ini dicoret?"

A1.7 : "Saya awalnya menggunakan gradien untuk menunjukkan kalau ini segaris mbak."

P : "Lalu?"

A1.8 : "Gak jadi saya pakai mbak makanya dicoret, soalnya gradien itu kemiringan mbak. Akhirnya saya pakai persamaan garis saja mbak"

P : "Kenapa begitu?"

A1.9 : "Kalau hasilnya sama nanti titiknya segaris." 
Pada tahap ini subjek A1 dapat meyebutkan respons dan alasannya dengan jelas dan mengungkapkan bahwa awalnya ia menggunakan konsep gradien seperti pada pernyataan A1.5 hingga A1.7. Subjek A1 juga mengomunikasikan responsnya ini secara detail bagaimana proses folding back yang ia alami dengan menggunakan bahasa yang mudah dipahami. Selanjutnya, subjek A1 menyebutkan pernyataan A1.8 dan A1.9 yang menunjukkan bahwa ia telah bergerak lagi ke lapisan image having. subjek A1 menyatakan bahwa ia menggunakan rumus persamaan garis untuk menyelidiki apakah ketiga titik tersebut berada pada satu garis yang sama. Pernyataan A1.8 dan A1.9 ini juga menunjukkan bahwa subjek A1 juga mampu memberikan alasan yang mendukung (memperkuat) pemilihan strateginya untuk menyelesaikan masalah. Setelah melakukan folding back, subjek A1 bergerak kembali menuju lapisan formalizing yang dikonfirmasi oleh kutipan wawancara berikut.

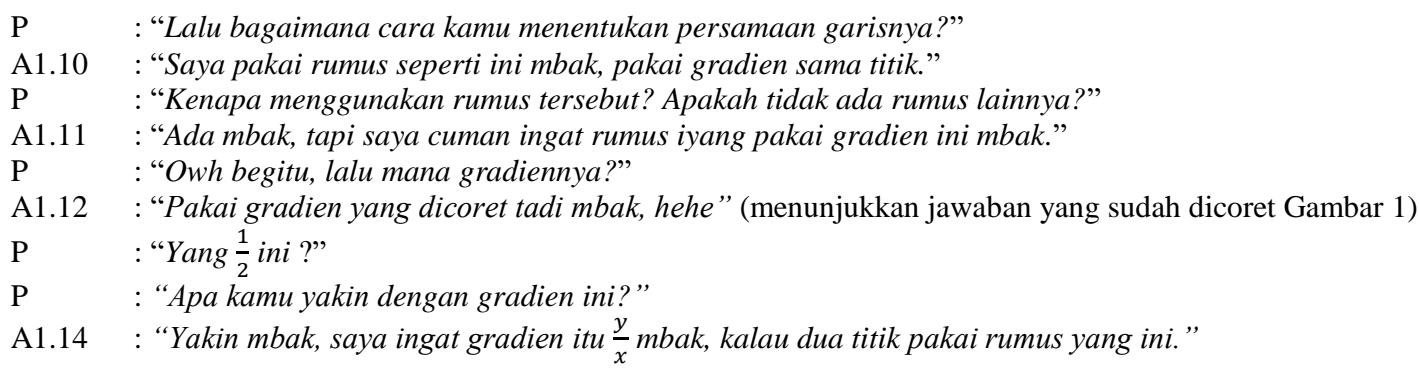

Kutipan wawancara di atas menunjukkan bahwa subjek A1 yang sudah berada dilapisan formalizing kembali lagi mengalami folding back ke lapisan image having. Folding back ini dilakukan secara mandiri untuk mengingat rumus persamaan garis berdasarkan informasi yang tersedia. Subjek A1 memberikan respons bahwa awalnya ia ingin menggunakan rumus persamaan garis melalui dua titik. Namun, subjek A1 akhirnya memutuskan untuk menggunakan rumus persamaan garis jika diketahui gradien dan satu titiknya. Ini terlihat pada pernyataan A1.10 dan A1.11 dimana subjek B1 memberikan respons yang jelas ketika menyebutkan pemilihan rumus persamaan garis yang akan ia gunakan. Pernyataan tersebut juga menunjukkan bahwa subjek B1 dapat mengomunikasikan pemilihan rumus yang digunakan dengan tepat, lancer, dan dapat memberikan alasan yang tepat dan mendukung pemilihan strategi yang digunakan. Selanjutnya, subjek A1 bergerak menuju lapisan formalizing untuk menuliskan perhitungan persamaan garis dari setiap titik yang diketahui. Berikut lanjutan jawaban tertulis subjek A1 beserta kutipan wawancara yang mengonfirmasi jawaban tersebut.

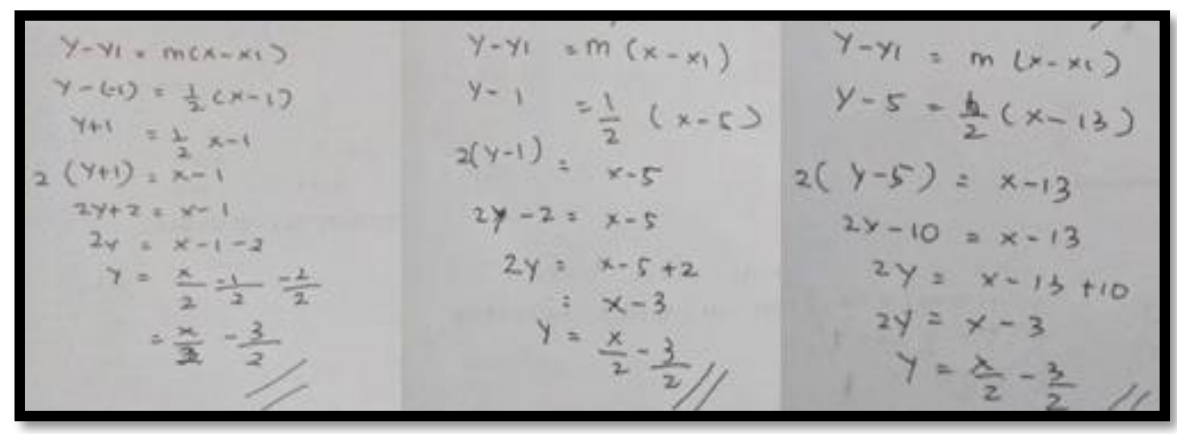

Gambar 2. Lanjutan Jawaban Subjek A1

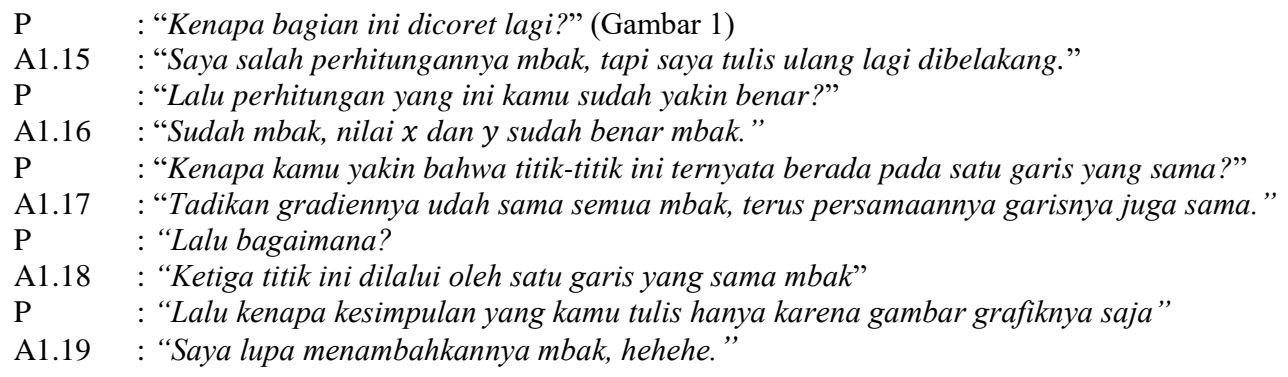

Pernyatan A1.15 menunjukkan bahwa subjek A1 kembali mengalami folding back dari lapisan formalizing ke lapisan primitive knowing. Folding back ini dilakukan untuk mengingat kembali cara mensubstitusikan nilai $x$ dan $y$ dari titik yang diketahui seperti pada pernyataan A1.15. Subjek A1 mengomunikasikan responsnya dengan jelas dan menggunakan bahasa yang mudah dipahami. Subjek A1 kemudian kembali bergerak menuju lapisan formalizing dengan menuliskan respons perhitungannya dengan jelas, benar dan terurut. Subjek A1 kemudian bergerak lagi menuju lapisan observing dengan 
menyebutkan pernyataan A1.17 dimana ia menemukan adanya kesamaan dari ketiga rumus persamaaan garis yang telah didapatkan. Pernyataan A1.17 ini juga menunjukkan bahwa subjek A1 sudah bergerak lagi menuju lapisan pemahaman structuring dengan menyebutkan pernyataan B1.18 hingga B1.19. Secara umum, subjek A1 memberikan respons tertulisnya dengan perhitungan yang jelas, terurut dan benar. Subjek A1 juga memberikan penjelasannya menggunakan bahasa yang mudah dipahami disertai alasan logis yang mendukung keseluruhan hasil perhitungan dan folding back yang dialaminya.

\section{Komunikasi Matematis Subjek B1 yang Mengalami Folding Back}

Subjek B1 menuliskan solusi penyelesaian yang berbeda dengan subjek A1. Subjek B1 memulai penyelesaian masalahnya dengan mencari gradien dari titik A dan C kemudian titik B dan C. Subjek B1 menuliskan respons perhitungannya ini dengan cukup jelas dan detail. Berikut Gambar 2 yang menunjukkan jawaban awal subjek B1 beserta kutipan wawancaranya.

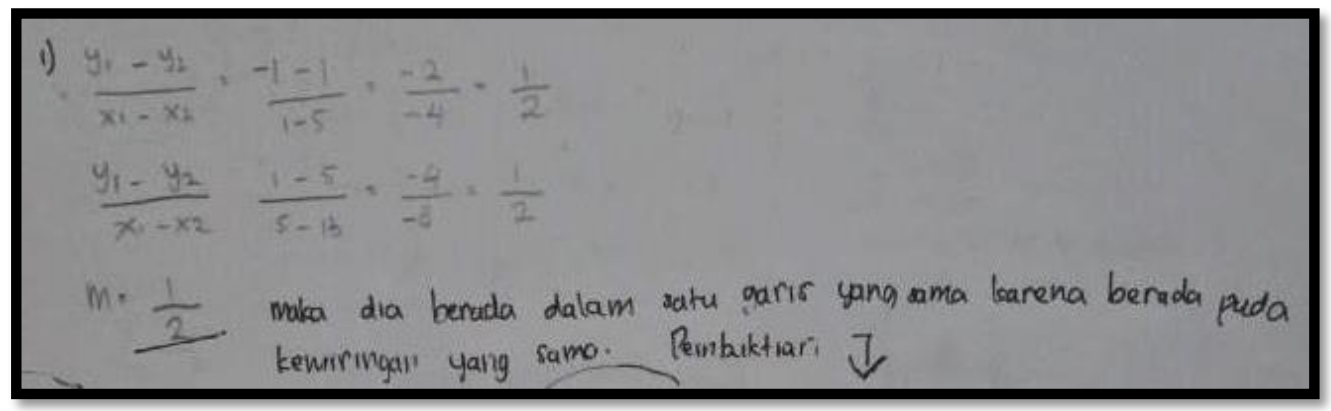

\section{Gambar 3. Jawaban Awal Subjek B1}

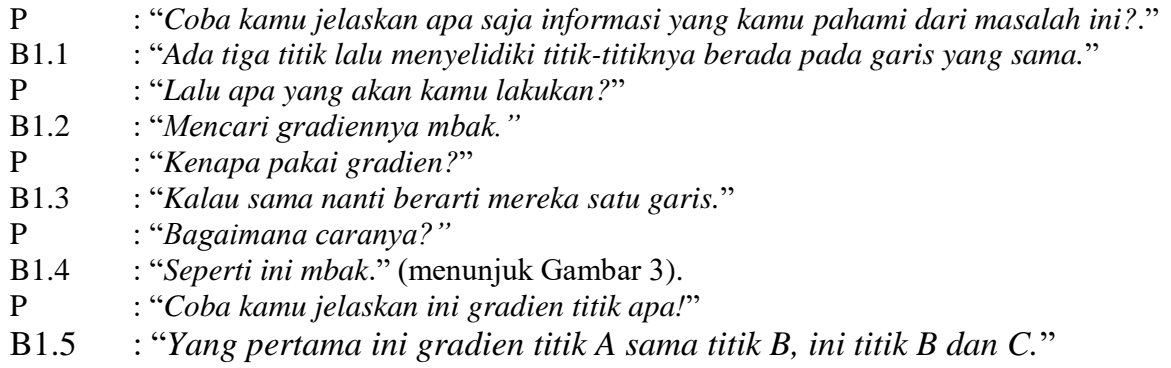

Secara tertulis subjek B1 sudah berada pada lapisan property noticing seperti yang terlihat pada gambar 3. Jawaban yang diberikan subjek B1 langsung menunjukkan perhitungannya saja dan tidak menunjukkan respons pemahaman awalnya terhadap masalah sehingga peneliti melakukan konfirmasi pemahamannya pada sesi wawancara. Subjek B1 kemudian memberikan respons dengan menyebutkan pernyataan B1.1 yaitu terdapat tiga titik yang akan diselidiki apakah berada pada satu garis yang sama. Ini berarti subjek B1 mengalami folding back ke lapisan primitive knowing dan kemudian bergerak menuju lapisan image making dan image having yang ditunjukkan oleh pernyataan B1.2 hingga B1.3. Subjek B1 menemukan bahwa titik-titik tersebut memiliki nilai gradien yang sama sehingga ia menyimpulkan bahwa ketiga titik tersebut sudah berada pada satu garis yang sama. Subjek dapat menjelaskan strategi dan kesimpulannya ini dengan lancar dan mudah dipahami namun strategi ini masih belum tepat untuk menyelesaikan masalah tersebut. Pada tahap ini subjek B1 mengalami folding back setelah adanya intervensi dari peneliti ketika melakukan wawancara. Peneliti memberikan bantuan berupa pertanyaan yang mengarahkan subjek untuk menemukan kaitan antara gradien dengan kedudukan garis dan menggunakan konsep persamaan garis untuk menyelesaikan masalah. Berikut kutipan lanjutan kutipan wawancara subjek B1.

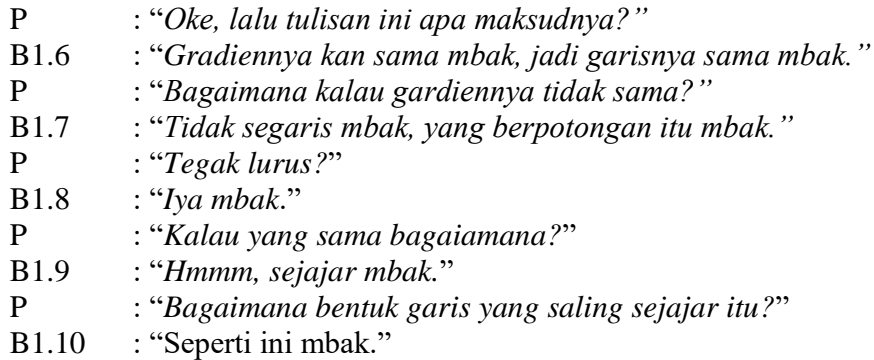




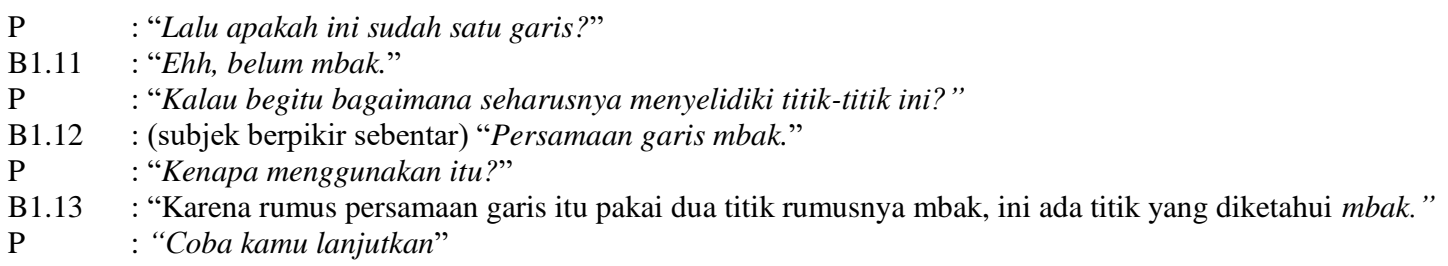

Kutipan wawancara di atas menunjukkan bahwa intervensi yang peneliti lakukan dapat membantu subjek menemukan strategi penyelesaian yang tepat. Subjek B1 mengalami folding back dari lapisan property noticing menuju lapisan image making dan didukung oleh pernyataan B1.7 hingga B1.11. Pernyataan B1.8 hingga B1.12 menunjukkan bahwa subjek B1 sedang melakukan proses untuk menemukan strategi yang dapat menyelesaikan masalah dengan bantuan pertanyaan dari peneliti. Sedangkan pernyataan B.12 hingga B.13 merupakan rencana/strategi baru yang disampaikan subjek untuk menyelesaikan masalah. Pernyataan B1.8 hingga B1.15 ini juga menunjukkan bahwa subjek dapat memberikan responsnya dengan jelas dan benar setelah melakukan folding back melalui intervensi ke lapisan image making. Hasil folding back ini ditunjukkan subjek melalui perhitungannya yang ditunjukkan oleh gambar 4.

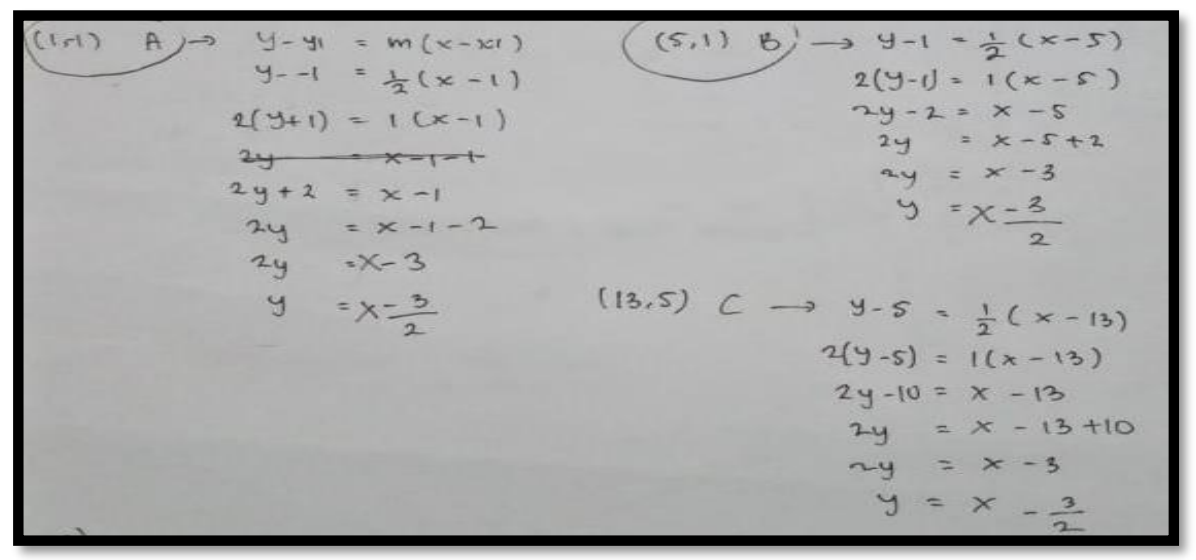

Gambar 4. Lanjutan Jawaban Subjek B1

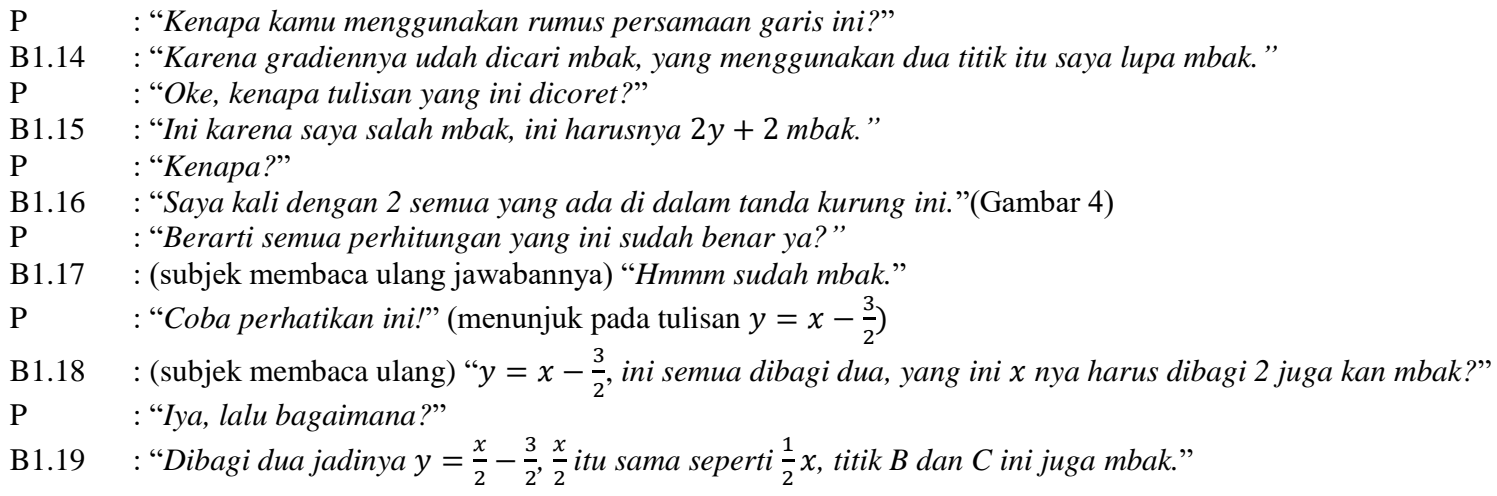

Gambar 4 menunjukkan bahwa folding back yang dilakukan subjek sebelumnya memberikan hasil yang efektif sehingga subjek B1 sudah bergerak ke lapisan formalizing. Subjek B1 menyatakan bahwa ia memilih rumus persamaan garis jika diketahui satu titik dan gradien karena sebelumnya gradien dari titik tersebut sudah ditemukan seperti pada pernyataan B1.14. Ketika subjek B1 mencari persamaan garis yang melewati titik A, ia kembali melakukan folding back kelapisan primitive knowing. Folding back ke lapisan primitive knowing ini terjadi sebanyak dua kali yaitu folding back secara mandiri dan folding back melalui intervensi peneliti sepert pada pernyataan B1.15 hingga B1.19. Folding back ini dilakukan untuk mengingat kembali operasi bilangan dan konsep penyerderhanaan pada bilangan. Subjek A1 mampu menunjukkan responsnya dengan jelas, terurut dan disertai alasan yang mendukung perhitungannya. Selanjutnya subjek B1 mulai bergerak kembali menuju lapisan observing hingga ke lapisan structuring. Berikut lanjutan potongan wawancara dengan subjek B1. 
P : "Kenapa kamu perlu mencari persamaan garis untuk masalah ini?"

B1.20 : "Gradien yang sama kan baru garisnya yang sejajar mbak, makanya saya cari persamaan garis mbak yang sama berarti titiknya berada pada satu garis mbak."

P : "Lalu bagaimana hasilnya?"

B1.21 : "Tiga-tiganya punya persamaan garis yang sama mbak."

P : "Kalau sama bagaimana?"

B1.22 : "Karena ketiga persamaan garisnya sama berarti titik tersebut berada pada satu garis yang sama mbak."

Kutipan wawancara di atas menunjukkan bahwa subjek B1 berada pada lapisan observing yang terlihat pada pernyataan B1.20 dan B1.21. Selanjutnya, pernyataan B.28 menunjukkan bahwa subjek B1 sudah bergerak ke lapisan structuring dengan memberikan kesimpulan dari keseluruhan solusi yang telah ia cari. Subjek B1 memberikan kesimpulan bahwa ketiga titik tersebut berada pada satu garis yang sama karena adanya kesamaan dari ketiga rumus persamaan garis yang telah dicari. Secara umum, subjek B1 dapat memberikan respons tertulisnya dengan benar setalah mengalami folding back melalaui intervensi peneliti. Perhitungan yang dituliskan subjek B1 menunjukkan respons yang jelas dan dikomunikasikan dengan efektif. Subjek B1 juga dapat memberikan alasan yang mendukung solusi penyelesaiannya setelah ia melakukan folding back dengan bantuan peneliti.

\section{PEMBAHASAN}

\section{Komunikasi Matematis Subjek yang Mengalami Folding Back}

Folding back pada penelitian ini dapat diamati melalui perilaku subjek ketika mengomunikasikan jawabannya, seperti adanya kesalahan atau coretan pada lembar jawaban subjek. Hal ini dapat mengindikasikan bahwa subjek mengalami folding back ketika menyelesaikan masalah (Hayati, 2018). Data hasil penelitian menunjukkan bahwa subjek dengan kemampuan tinggi mengalami folding back secara mandiri tanpa diperlukannya bantuan dari peneliti. Folding back ini juga memberikan hasil yang efektif bagi subjek berkemampuan tinggi untuk menemukan penyelesaiannya. Ini didukung oleh penelitian Hayati (2018) yang menyatakan bahwa subjek berkemampuan tinggi memiliki pemahaman/pengetahuan yang cukup untuk melakukan folding back secara mandiri sehingga intervensi dari pihak lainnya tidak terlalu diperlukan. Sementara itu, folding back dengan hasil yang efektif maksudnya adalah folding back yang dilakukan siswa memberikan hasil yang tepat untuk menemukan penyelesaian akhir yang dapat menjawab pertanyaan masalah dengan benar (Martin, 2008). Subjek dengan kemampuan sedang masih memerlukan intervensi peneliti untuk melakukan folding back ke lapisan yang diperlukan. Ini sesuai dengan penelitian Hayati (2018) yaitu intervensi berupa pertanyaan bantuan dapat memicu terjadinya folding back menuju lapisan yang diperlukan siswa untuk menyelesaikan masalah. Selain itu, Pirie \& Kieren (1994) menyatakan bahwa intervensi ini diperlukan untuk membantu subjek menguhubungkan pemahamannya yang berkaitan dengan permasalahan sehingga ia dapat bergerak ke lapisan pemahaman selanjutnya. Intervensi yang dilakukan pada waktu dan kondisi yang tepat merupakan cara yang efektif untuk membantu mengembangkan pemahaman siswa yang mengalami hambatan pada lapisan tertentu (Borgen \& Manu, 2002; Towers, 1998).

Subjek berkemampuan tinggi secara tertulis tidak memberikan responsnya secara detail pada setiap tahapan penyelesaian masalah. Ini disebabkan kebiasaan subjek yang hanya berfokus pada perhitungannya saja dalam menyajikan solusi masalahnya. Walaupun begitu respons tertulis yang diberikan subjek berkemampuan tinggi ini dapat dipahami karena dituliskan dengan jelas, benar, dan terurut sehingga dapat dipahami bagaiamana arah berpikir subjek dalam menyelesaikan masalah dan folding back yang dialaminya. Subjek dengan lancar dapat menjelaskan informasi awal yang ia pahami, strategi yang digunakan serta memberikan kesimpulan dari penyelesaiannya. Ini dilakukan agar dapat melihat lebih detail komunikasi subjek dengan meminta mereka untuk mengidentifikasi informasi penting yang disajikan pada permasalahan (Olteanu \& Olteanu, 2012). Ini mengindikasikan bahwa subjek berkemampuan tinggi ini dapat mengomunikasikan respons atau penjelasannya ini dengan efektif dan menggunakan bahasa sendiri yang mudah dipahami oleh peneliti. Temuan ini didukung oleh penelitian Hayati (2018) yang menyatakan bahwa subjek berkemampuan tinggi cenderung memberikan penjelasan atau responsnya secara lisan tanpa menuliskannya pada lembar jawaban. Penjelasan ini juga menunjukkan bahwa subjek berkemampuan tinggi sudah mampu memberikan argumen yang mendukung solusi jawaban yang diberikan karena memiliki pemahaman yang baik pada materi yang diujikan. Ini sesuai dengan (NCTM, 2000) yaitu siswa tingkat menengah harus mampu mengomunikasikan pemikirannya dengan efektif agar dapat dipahami dan disertai argumen yang dapat dipertimbangkan kebenarannya.

Subjek berkemampuan sedang secara tertulis menuliskan respons perhitungannya dengan cukup jelas dan terurut, namun masih terdapat kesalahan dalam penggunaan rumus persamaan garis dan perhitungan operasi bilangannya. Subjek berkemampuan sedang memiliki kebiasaan untuk menuliskan pemahaman awalnya jika ia belum menemukan strategi yang tepat untuk menyelesaikan suatu masalah. Hal ini dilakukan subjek agar poin untuk penilaian akhir dari gurunya. Hal ini diperkuat oleh guru yang mengajar bahwa siswanya terbiasa untuk menuliskan pemahaman awalnya yaitu apa yang diketahui dan ditanyakan dari permasalahan untuk memperoleh beberapa poin penilaian jika mereka belum menemukan penyelesaian dari suatu masalah tersebut. Temuan ini juga sesuai dengan teori belajar Pavlov yang menyatakan bahwa adanya konsep pembiasaan dalam proses pembelajaran. Secara umum, subjek berkemampuan sedang sudah memberikan respons tertulis yang cukup jelas dan terurut. Namun, subjek masih kurang efektif dalam mengomunikasikan responsnya secara tertulis sehingga masih 
diperlukan penjelasan lebih lanjut untuk memahami arah penyelesaian jawaban yang diberikan. Subjek berkemampuan sedang juga belum mampu memberikan argumen yang tepat untuk mendukung jawabannya sehingga diperlukannya bantuan atau intervensi peneliti untuk melakukan folding back sehingga menemukan penyelesaian masalah yang benar.

Deskripsi di atas menunjukkan bahwa subjek berkemampuan tinggi memiliki komunikasi matematis yang lebih baik dalam menyajikan solusinya dibandingkan subjek dengan kemampuan sedang. Hal ini disebabkan pemahaman subjek berkemampuan tinggi lebih baik pada materi persamaan garis dibandingkan subjek berkemampuan sedang. Paparan data juga menunjukkan bahwa subjek berkemampuan tinggi melakukan folding back secara mandiri dan memberikan hasil yang efektif pada solusinya. Subjek berkemampuan sedang masih membutuhkan bantuan atau intervensi dari peneliti untuk hingga ditemukannya penyelesaian yang tepat. Ini menunjukkan bahwa pemahaman konsep subjek juga memengaruhi cara siswa menyajikan dan mengomunikasikan penyelesaiannya secara efektif kepada pihak lainnya. Ini didukung pernyataan Kallick yaitu komunikasi matematis siswa dapat dinilai salah satunya melalui pemahaman konsep yang dimiliki siswa (dalam Cai dkk., 1996). Selanjutnya (NCTM, 2000) juga menyatakan bahwa siswa yang menguasai atau memahami konsep maka siswa tersebut akan mampu mengomunikasikan penyelesaian masalah dengan efektif disertai argumen yang dapat mendukung penyelesaian jawabannya.

Setiap subjek pada penelitian ini memiliki komunikasi matematis yang beragam ketika menyajikan respons penyelesaian masalahnya. Temuan penelitian ini sesuai dengan pendapat (Cai dkk, 1996) yaitu masing-masing siswa memiliki gaya berbeda dalam mengomunikasikan pemikirannya secara tulisan, lisan, ekspresi maupun gambar. Subjek berkemampuan tinggi maupun sedang memiliki kebiasaan hanya menuliskan perhitungannya saja. Namun, peneliti menemukan bahwa adanya kecenderungan subjek untuk menuliskan informasi awal yang sesuai dengan Pernyataan tersebut didukung oleh Honey-Mumford yang menyatakan bahwa setiap siswa memiliki karakter berbeda ketika menyelesaikan masalah yaitu (1) kecenderungan mengerjakan masalah secara prosedural dan (2) mengerjakan masalahan sesuai dengan ketentuan atau petunjuk pengerjaan masalah (dalam Pritchard, 2009).

\section{SIMPULAN}

Berdasarkan pembahasan dan temuan penelitian yang telah dipaparkan maka dapat disimpulkan bahwa setiap subjek mempunyai komunikasi matematis beragam dalam menyampaikan responsnya. Subjek berkemampuan tinggi cenderung memberikan respons yang tidak terlalu detail pada lembar jawabannya seperti tidak menuliskan pemahaman awalnya, ataupun tidak menuliskan kesimpulan akhir dari penyelesaian yang ia tuliskan. Subjek berkemampuan tinggi terbiasa menuliskan responsnya hanya berupa perhitungannya saja. Perhitungan ini dituliskan subjek dengan lengkap, jelas, dan terurut sehingga dapat memberikan gambaran proses penyelesaian masalah yang dipikirkan oleh subjek. Subjek berkemampuan tinggi juga mampu memberikan argumen yang mendukung solusi jawaban yang diberikan karena memiliki pemahaman yang baik pada materi persamaan garis lurus. Subjek berkemampuan sedang secara tertulis menuliskan respons perhitungannya dengan cukup jelas dan terurut namun masih terdapat kesalahan dalam penggunaan rumus persamaan garis dan perhitungan operasi bilangannya. Subjek juga masih kurang efektif dalam mengomunikasikan responsnya secara tertulis masih diperlukan penjelasan lebih lanjut untuk memahami arah penyelesaian jawaban yang diberikan. Selain itu, subjek berkemampuan sedang juga belum mampu memberikan argumen yang tepat untuk mendukung jawabannya sehingga diperlukan bantuan atau intervensi peneliti untuk membantu subjek menemukan penyelesaian masalah yang tepat.

Berdasarkan deskripsi dan temuan penelitian, maka peneliti menyarankan kepada guru untuk membiasakan subjek berkemampuan tinggi menuliskan lebih detail responsnya terhadap suatu masalah. Untuk subjek berkemampuan sedang, guru diharapkan dapat memberikan bantuan atau scaffolding yang bertujuan untuk membantu subjek agar dapat lebih memahami masalah yang dihadapi dan bisa menuliskan responsnya dengan benar disertai penjelasan yang mendukung. Scaffolding yang diberikan kepada subjek dapat dilakukan beberapa kali sampai siswa mampu menemukan penyelesaian masalah yang tepat.

\section{DAFTAR RUJUKAN}

Borgen, K. L., \& Manu, S. S. (2002). What Do Students Really Understand?. The Journal of Mathematical Behavior, 21(2), 151-165. https://doi.org/10.1016/S0732-3123(02)00115-3

Brookhart, S. M. (2010). How To Assess Higher-Order Thinking Skills in Your Classroom. Alexandria, Va: ASCD.

C. Martin, L. (2008). Folding Back and The Dynamical Growth of Mathematical Understanding: Elaborating the Pirie-Kieren Theory (Vol. 27). https://doi.org/10.1016/j.jmathb.2008.04.001

Cai, J., Jakabcsin, M. S., \& Lane, S. (1996). Assessing Students' Mathematical Communication. School Science and Mathematics, 96(5), 238-246. https://doi.org/10.1111/j.1949-8594.1996.tb10235.x

Hayati, F.A. (2018). Folding Back Siswa Kelas VIII SMP Dalam Menyelesaikan Masalah Persamaan Garis Lurus dan Intervensinya. Tesis tidak diterbitkan. Universitas Negeri Malang, Malang.

Kilpatrick, J., Swafford, J., Findell, B., \& National Research Council (U.S.) (Eds.). (2001). Adding It Up: Helping Children Learn Mathematics. Washington, DC: National Academy Press.

National Council of Teachers of Mathematics (Ed.). (2000). Principles and Standards for School Mathematics. Reston, VA: National Council of Teachers of Mathematics. 
Olteanu, C., \& Olteanu, L. (2012). Equations, Functions, Critical Aspects and Mathematical Communication. International Education Studies, 5(5). https://doi.org/10.5539/ies.v5n5p69

Pirie, S. E. B., \& Kieren, T. E. (1989). A Recursive Theory of Mathematical Understanding. For the Learning of Mathematics, 9(3), 7-11.

Pirie, S., \& Kieren, T. (1994). Growth in Mathematical Understanding: How Can We Characterise It and How Can We Represent It?. Educational Studies in Mathematics, 26(2-3), 165-190. https://doi.org/10.1007/BF01273662

Pirie, S., \& Martin, L. (2000). The Role of Collecting in The Growth of Mathematical Understanding. Mathematics Education Research Journal, 12(2), 127-146. https://doi.org/10.1007/BF03217080

Pritchard, A. (2009). Ways of Learning: Learning Theories and Learning Styles in The Classroom (2nd ed). Abingdon, Oxon; New York, NY: Routledge.

Towers, J. M. (1998). Teachers' Interventions and The Growth of Students' Mathematical Understanding. The University of British Columbia. https://doi.org/10.14288/1.0054923

Uptegrove, E. B. (2015). Shared Communication in Building Mathematical Ideas: A Longitudinal Study. The Journal of Mathematical Behavior, 40, 106-130. https://doi.org/10.1016/j.jmathb.2015.02.001

Walle, J. A. V. de, Karp, K. S., \& Bay-Williams, J. M. (2010). Elementary and Middle School Mathematics, Teaching Developmentally (7. ed., Pearson internat. ed). Boston: Allyn \& Bacon.

Yoe, K. K. J. (2009). Secondary 2 Students' Difficulties in Solving Non-Routine Problems. International Journal for Mathematics Teaching and Learning, 1-30. 